\title{
THE LIFE OF NORTH AMERICAN SUBURBS
}

\section{Imagined Utopias and Transitional Spaces}

Edited by Jan Nijman

This book chronicles and explains the role of suburbs in North American cities since the mid-20th century. Examining 15 far-flung case studies - from New York to Vancouver, Atlanta to Chicago, Montreal to Phoenix - The Life of North American Suburbs traces the insightful connection between the evolution of suburbs and the cultural dynamics of modern society. Suburbs are uniquely significant spaces: their creation and evolution reflect the shifting demographics, race relations, modes of production, cultural fabric, and class structures of society at large. The case studies presented here investigate the place of suburbs within their wider metropolitan constellations, examining the crucial role they play in the cultural, economic, political, and spatial organization of the city. Together, the chapters paint a compelling portrait of North American cities and their dynamic suburban landscapes, which have evolved to defy traditional conceptions of the postwar suburban neighborhood.

(Global Suburbanisms)

JAN NIJMAN is director of and distinguished professor at the Urban Studies Institute at Georgia State University and a professor of geography at the University of Amsterdam. 


\section{GLOBAL SUBURBANISMS}

Series Editor: Roger Keil, York University

Urbanization is at the core of the global economy today. Yet, crucially, suburbanization now dominates 21st-century urban development. This book series is the first to systematically take stock of worldwide developments in suburbanization and suburbanisms today. Drawing on methodological and analytical approaches from political economy, urban political ecology, and social and cultural geography, the series seeks to situate the complex processes of suburbanization as they pose challenges to policymakers, planners, and academics alike.

For a list of the books published in this series, see page 387. 


\title{
EDITED BY JAN NIJMAN
}

\section{The Life of North American Suburbs}

\author{
Imagined Utopias and \\ Transitional Spaces
}

UNIVERSITY OF TORONTO PRESS Toronto Buffalo London 
(C) University of Toronto Press 2020

Toronto Buffalo London

utorontopress.com

Printed in the U.S.A.

ISBN 978-1-4875-0109-9 (cloth)

ISBN 978-1-4875-1247-7 (EPUB)

ISBN 978-1-4875-2077-9 (paper) ISBN 978-1-4875-1246-0 (PDF)

\section{Library and Archives Canada Cataloguing in Publication}

Title: The life of North American suburbs : imagined utopias and transitional spaces / edited by Jan Nijman.

Names: Nijman, Jan, editor.

Series: Global suburbanisms.

Description: Series statement: Global suburbanisms | Includes bibliographical references and index.

Identifiers: Canadiana (print) 20190211067 | Canadiana (ebook) 20190211075 | ISBN 9781487501099 (cloth) I ISBN 9781487520779 (paper) | ISBN 9781487512460 (updf) | ISBN 9781487512477 (epub)

Subjects: LCSH: Suburbs - North America. I LCSH: Cities and towns - North America - Growth. I LCSH: Urbanization - North America.

Classification: LCC HT352.N7 L54 2019 | DDC 307.76097 - dc23

University of Toronto Press acknowledges the financial assistance to its publishing program of the Canada Council for the Arts and the Ontario Arts Council, an agency of the Government of Ontario.

Canada Council for the Arts
Conseil des Arts du Canada
ONTARIO ARTS COUNCIL CONSEIL DES ARTS DE L'ONTARIO

an Ontario government agency un organisme du gouvernement de l'Ontario 